\title{
Genetic differentiation and natural hybridization between two morphological forms of the common woodlouse, Oniscus asellus Linnaeus 1758
}

\author{
D. T. BILTON*†, D. GOODE $+\&$ J. MALLET\& \\ $\dagger$ Department of Biological Sciences and Plymouth Environmental Research Centre, University of Plymouth, Drake \\ Circus, Plymouth PL4 8AA, U.K., $\$$ Natural History Museum, Cromwell Road, London SW7 5BD, U.K. and $\S$ Galton \\ Laboratory, Department of Biology, University College London, 4 Stephenson Way, London NW1 2HE, U.K.
}

\begin{abstract}
The common woodlouse Oniscus asellus can be divided into two forms on the basis of morphology, particularly male accessory genitalia. Where these taxa meet, morphological intermediates are found, and the forms were therefore described as subspecies; $O$. a. asellus and $O$. a. occidentalis. In this study allozyme loci are used to test the hypothesis that intermediate forms result from hybridization, and to study the nature of hybridization. Thirteen enzyme loci were scored across five English sites representative of each subspecies and intermediates. Ten loci showed strong frequency differences between asellus and occidentalis populations, although no loci showed completely fixed differences. These data confirm that asellus and occidentalis represent genetically distinct taxa, and that intermediate populations are of hybrid origin. There is apparently substantial population substructuring in the contact zone, as indicated by deficits of heterozygotes $\left(F_{\mathrm{IS}}\right)$ and sporadic gametic (i.e. linkage) disequilibria. Population structure in the Oniscus hybrid zone appears to be analogous to that seen in plant hybrid swarms rather than the narrow hybrid zones observed in many animal taxa. Values of Nei's genetic distance between the subspecies range from 0.65 to 0.70 ; these are much higher than between typical conspecific taxa and are indicative of ancient genetic divergence. However, because asellus and occidentalis do not remain distinct in areas of overlap, it is simplest to regard these taxa as members of the same species.
\end{abstract}

Keywords: allozymes, hybrid zone, linkage disequilibrium, Oniscus, subspecies.

\section{Introduction}

The woodlouse Oniscus asellus Linnaeus is one of the most widespread and abundant terrestrial arthropods in Western Europe. Bilton (1994) demonstrated that the species could be divided into two distinct subspecies: Oniscus asellus asellus Linnaeus and $O$. asellus occidentalis Bilton. The two taxa are ecologically and biogeographically distinct as well as differing in morphology. True asellus is widespread, particularly in synanthropic (human-influenced) sites. On the other hand, occidentalis is recorded only from sites in the south-west of the British Isles and western France (Bilton, 1994, 1997). Intermediate populations occur throughout the range of occidentalis, and also further east, where they are increasingly confined to wet

*Correspondence. E-mail: dbilton@plym.ac.uk habitats. Bilton (1994) suggested that the numerous populations with intermediate morphology arose via hybridization between the two subspecific taxa. This paper presents the results of an allozyme study of five populations of Oniscus asellus s. lat. to test the hypothesis that hybridization explains the intermediate morphologies found, and to study the nature of the hybridization. We provide genetic evidence of strong divergence between the taxa and discuss the status of these forms.

\section{Materials and methods}

\section{Site selection and specimen collection}

Oniscus specimens were collected from three sites in Devon (Wistman's Wood [ancient Quercus petraea woodland; occidentalis], Lydford Gorge [managed mixed woodland; intermediates] and Braunton [village garden; 
intermediates]) together with sites in Northumberland (Riding Woods [seminatural Quercus robur wood; asellus]) and London (Highbury [urban garden; asellus]).

At each locality Oniscus specimens were collected by hand searching in humid shelter sites such as beneath moss and bark on rotting logs. Only males were selected because female occidentalis and intermediate morphs are not reliably separable from asellus (Bilton, 1994). Woodlice were brought alive to the laboratory, where they were scored as asellus, occidentalis or intermediates on the basis of male genitalia, before being transferred directly to a $-70^{\circ} \mathrm{C}$ freezer for storage prior to allozyme studies.

\section{Allozyme electrophoresis}

For allozyme studies the head and pereon (leg-bearing segments) of each individual were removed, and the pleon (hind body) stored in ethanol for further study of the accessory genitalia. Each pereon was homogenized

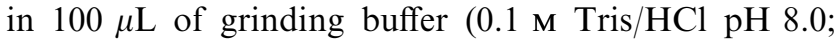
five drops of $\beta$-mercaptoethanol $/ 100 \mathrm{~mL}$ ). The homogenate was then centrifuged for $5 \mathrm{~min}$ at $10000 \mathrm{~g}$ in a microcentrifuge and stored on ice.

\section{Electrophoresis and enzyme staining}

A total of 23 enzyme systems were initially screened. Of these, 12 (aconitase, adenosine deaminase, adenylate kinase, esterase, fumarase, glucose-3-phosphate dehydrogenase, glucose-6-phosphate dehydrogenase, $\alpha$-glucose phosphate dehydrogenase, glutathione reductase, hexokinase, isocitrate dehydrogenase and nucleoside phosphorylase) showed no activity or were unscorable, leaving 11 enzyme systems with a total of 13 scorable loci (acid phosphatase, Acp; enolase, Eno; glutamicoxaloacetic transaminase, Got-1, Got-2; glucose-6-phosphate isomerase, Gpi; malate dehydrogenase, $M d h$; malic enzyme, $M e$; mannose-6-phosphate isomerase, $M p i$; peptidase (leucine glycine glycine), Lgg-1, Lgg-2; peptidase (phenylalanine proline) $P p$; phosphoglucomutase, Pgm; and sorbitol dehydrogenase, $S d h)$. The running conditions on cellulose acetate gels were: $A c p$, Eno, Got-1, Got-2 and Mdh, phosphate buffer, $20 \mathrm{~min}$ at $200 \mathrm{~V}$; Pp, Tris-glycine, $15 \mathrm{~min}$ at $200 \mathrm{~V}$; all other enzymes, Tris-glycine, $20 \mathrm{~min}$ at $200 \mathrm{~V}$. Buffers were as follows: Phosphate buffer, $20 \mathrm{~mm} \mathrm{NaH} \mathrm{PO}_{4}, 6 \mathrm{~mm}$ $\mathrm{Na}_{2} \mathrm{HPO}_{4}$, pH 6.3; Tris-glycine, $20 \mathrm{~mm}$ Tris base, $200 \mathrm{~mm}$ glycine, $\mathrm{pH}$ 8.0. Enzyme staining followed Easteal \& Boussy (1987), Emelianov et al. (1995) and Richardson et al. (1986).

\section{Data analysis}

The following were calculated for each of the five localities: mean number of alleles per locus, percentage of loci polymorphic (95 and 99\% criteria) and mean heterozygosity. Population structure and deviations from Hardy-Weinberg equilibrium were assessed using $F$-statistics (Wright, 1965, 1978).

To display the genotypic structure within the hybrid zone, a 'hybrid index' was constructed based on allelic differentiation between the two taxa. Alleles at each of the 10 differentiated loci were classed as typical of either asellus or occidentalis. The hybrid index value of an individual represents the proportion of asellus alleles that it carries, and varies between 0 and 1 .

To assess population structure and gene flow between the two taxa further, pairwise linkage disequilibria (gametic correlations) were estimated for each population between each of the 10 differentiated loci. Because we were interested in gene flow between taxa, we lumped alleles at each locus if they belonged to the same taxon. Thus each locus was treated as if it had only two alleles: $O$ (occidentalis) and $A$ (asellus). With 10 loci, this procedure also reduces the number of pairwise disequilibria to be estimated to 45 per site. Maximum likelihood pairwise linkage disequilibria were calculated and their significance tested following Hill (1974). We estimated the correlation coefficient $R_{i j}$ to within an accuracy of 0.01 for each pair of loci $i$ and $j$. The correlation coefficient is calculated because it varies between 0 and 1 , allowing a comparison of disequilibria between loci of different frequencies. The correlation coefficient is a standardization of the disequilibrium coefficient, $D_{i j}$, as follows:

$R_{i j}=\frac{D_{i j}}{\sqrt{p_{i}\left(1 \quad p_{i}\right) p_{j}\left(1 \quad p_{j}\right)}}$.

The correlation coefficient has been criticized as a measure of linkage disequilibrium on the grounds that it is dependent on the allele frequencies $p_{i}$ and $p_{j}$ (Hedrick, 1987). However, the alternative standardization recommended by Hedrick (Lewontin's $D_{i j}{ }^{*}$ ) has its own problems: although its limits are not frequencydependent, its value is frequency-dependent; $D_{i j}{ }^{*}$ is also statistically intractable because it is a discontinuous function (Lewontin, 1988). There is no easy solution to this problem of standardization, which is useful to compare disequilibria across loci which differ in $p_{i}$ and $p_{j}$. We here adopt the correlation coefficient which is at least familiar from other statistical problems. Hill's likelihood method for estimating the within-gamete disequilibrium, $D_{i j}$, implicitly makes the assumption that the between-gamete disequilibrium, $D_{i / j}$, is zero (Weir, 1990). This assumption seems reasonable provided that $F_{\mathrm{IS}}=0$ ( $F_{\mathrm{IS}}$ is essentially a within-locus between-gamete disequilibrium). Unfortunately, we find 
here that $F_{\text {IS }}$ is frequently nonzero, although the reasons for this may be in some cases more to do with scoring difficulties or possible hemizygosity of sex-linked loci than true absence of heterozygotes. Because the gametic arrangements of double heterozygotes cannot be detected from allozyme data, our estimate of $D_{i j}$ is equivalent to Weir's $\Delta \mathrm{ij}=D_{i j}+D_{i j j}$.

Nei's unbiased genetic identity, $I$, and genetic distance, $D_{N}($ Nei, 1972, 1986) were calculated between populations. Genetic identities were then clustered using the neighbour-joining technique, correcting for negative branch lengths (negative branch lengths set to zero; Felsenstein, 1993; Swofford et al., 1997). Calculations were carried out using BIosys-1 (Swofford \& Selander, 1989), except for calculations of disequilibria, which were performed using a computer program written by $\mathbf{J}$. M., and the neighbour-joining tree construction which was performed using PHYLIP version 3.5c (Felsenstein, 1993).

\section{Results}

\section{Morphological scoring}

The population from Wistman's Wood consisted of pure $O$. asellus occidentalis, based on male accessory genital morphology (Bilton, 1994). Using the same criteria the populations from North London and Northumberland were $O$. asellus asellus, which is the only form known from either of these regions (Bilton, 1994). The Braunton sample consisted of intermediate individuals. Specimens from Lydford were of mixed morphology; 33 specimens approximated $O$. asellus asellus on male genital morphology, although they also had some narrowing of body form and pale pereon markings characteristic of occidentalis and intermediate populations, suggesting that these individuals too were of mixed origin (Bilton, 1994). Three additional specimens from Lydford could be classified as occidentalis on male characteristics. Overall the population was considered to be intermediate in character between asellus and occidentalis.

\section{Allele frequencies}

Table 1 presents allele frequencies at scorable loci for the five populations investigated. All 13 loci show some degree of variation within and between populations. At 10 loci (Eno, Got-1, Got-2, Lgg-1, Lgg-2, Mdh, Me, $M p i, \quad P g m$ and $P p$ ) there were $>30 \%$ frequency differences at at least one allele between the asellus and occidentalis samples. Thirty-one alleles at 10 semidiagnostic loci were used to calculate a 'hybrid index' for individuals within each population (Fig. 1), which clearly characterizes the morphologically intermediate Braunton and Lydford populations as genetically intermediate. These also had allele frequencies at diagnostic loci intermediate between those of Wistman's Wood (occidentalis) or London/Northumberland (asellus; see Fig. 1). In addition, individuals from mixed populations were themselves genetically intermediate, rather than bimodal with individuals genetically similar to one or other parent.

\section{Levels of genetic variability within populations}

All three measures of genetic variability (Table 2) are lower in $O$. asellus asellus populations (London and Northumberland) than in those consisting of occidentalis (Wistman's) or intermediates (Lydford and Braunton). Heterozygosity in intermediate populations was about double that in pure populations.

\section{Population structure}

Values of $F_{\text {IS }}$ in Table 3 indicate significant deviations from Hardy-Weinberg equilibrium at a number of loci, all of these being the result of heterozygote deficiencies $\left(F_{\text {IS }}>0\right)$. Me shows a highly significant heterozygote deficiency in all populations, which may, however, result from scoring inaccuracies, sex linkage or null alleles, as no heterozygotes were scored $\left(F_{\mathrm{IS}}=1.00\right)$, even from polymorphic populations; the difficulties were compounded because homozygotes were themselves doublebanded on the cellulose acetate plates. Although results for this locus must be treated with caution, $M e$ is included here because it could still have proved informative for linkage disequilibrium, and genetic differentiation was observed between the populations studied. Mpi and Pgm also had high values of $F_{\text {IS }}$ in most populations. The sporadic pattern observed across the other loci could result from inbreeding or from the pooling of subpopulations which differ in allele frequency.

\section{Gametic disequilibria}

Gene flow between genetically differentiated populations at selection/gene flow equilibrium is liable to produce strong gametic phase disequilibria. Such disequilibria can be used to measure gene flow between populations. We therefore tested for pairwise disequilibrium amongst the 10 differentiated loci, using the alleles recoded according to subspecies of origin (Table 1). Thus, at each differentiated locus, all occidentalis alleles were lumped, and all asellus alleles were lumped. If significant levels of recent gene flow had been occurring, we would expect that significant levels of positive $R$ would be found in the morpho- 
logically and genetically intermediate populations at Lydford Gorge and Braunton. Instead, the average value of the disequilibrium coefficient $R$ was low across all populations, and not significantly different from 0 (Table 3 ). Nor is there an obvious pattern of significant disequilibria across loci (Table 4). The two intermediate populations (Lydford, Braunton) do have marginally more significant disequilibria, six and nine out of 45, respectively, than pure occidentalis (Wistman's: two significant disequilibria) and pure asellus

Table 1 Summary of allele frequencies at all loci in Oniscus asellus s. lat. (and see next page)

\begin{tabular}{|c|c|c|c|c|c|c|c|}
\hline \multirow[b]{2}{*}{ Locus* } & \multirow[b]{2}{*}{ Allele } & \multirow[b]{2}{*}{$\begin{array}{c}\text { Allele in } \\
\text { hybrid index } \dagger t\end{array}$} & \multicolumn{5}{|c|}{ Population } \\
\hline & & & $\begin{array}{l}\text { Wistman's } \\
\text { Wood }\end{array}$ & $\begin{array}{l}\text { Lydford } \\
\text { Gorge }\end{array}$ & Braunton & London & $\begin{array}{l}\text { Northum- } \\
\text { berland }\end{array}$ \\
\hline \multirow[t]{4}{*}{$A c p$} & $(N)$ & & 59 & 34 & 30 & 31 & 36 \\
\hline & A & - & 0.008 & 0.015 & 0.050 & 0.000 & 0.000 \\
\hline & B & - & 0.992 & 0.985 & 0.933 & 1.00 & 0.972 \\
\hline & $\mathrm{C}$ & - & 0.000 & 0.000 & 0.017 & 0.000 & 0.028 \\
\hline \multirow[t]{3}{*}{ Eno* } & $(N)$ & & 75 & 35 & 32 & 32 & 36 \\
\hline & A & A & 0.073 & 0.614 & 0.219 & 0.969 & 1.00 \\
\hline & B & $\mathrm{O}$ & 0.927 & 0.386 & 0.781 & 0.031 & 0.000 \\
\hline \multirow[t]{4}{*}{ Got-1* } & $(N)$ & & 75 & 36 & 32 & 32 & 36 \\
\hline & A & A & 0.100 & 0.778 & 0.672 & 0.844 & 0.972 \\
\hline & B & $\mathrm{O}$ & 0.713 & 0.153 & 0.281 & 0.156 & 0.028 \\
\hline & $\mathrm{C}$ & $\mathrm{O}$ & 0.187 & 0.069 & 0.047 & 0.000 & 0.000 \\
\hline \multirow[t]{3}{*}{ Got-2* } & $(N)$ & & 63 & 36 & 32 & 32 & 26 \\
\hline & A & A & 0.071 & 0.750 & 0.188 & 0.938 & 1.00 \\
\hline & B & $\mathrm{O}$ & 0.929 & 0.250 & 0.813 & 0.063 & 0.000 \\
\hline \multirow{3}{*}{ Gpi } & $(N)$ & & 75 & 35 & 32 & 32 & 36 \\
\hline & A & - & 0.033 & 0.186 & 0.078 & 0.047 & 0.000 \\
\hline & B & - & 0.967 & 0.814 & 0.922 & 0.953 & 1.00 \\
\hline \multirow{5}{*}{$\operatorname{Lgg}-1^{*}$} & $(N)$ & & 72 & 35 & 31 & 31 & 35 \\
\hline & A & $\mathrm{O}$ & 0.868 & 0.257 & 0.532 & 0.016 & 0.000 \\
\hline & B & A & 0.132 & 0.743 & 0.468 & 0.968 & 0.857 \\
\hline & $\mathrm{C}$ & A & 0.000 & 0.000 & 0.000 & 0.016 & 0.129 \\
\hline & D & A & 0.000 & 0.000 & 0.000 & 0.000 & 0.014 \\
\hline \multirow[t]{5}{*}{$\operatorname{Lgg}-2^{*}$} & $(N)$ & & 69 & 35 & 32 & 31 & 36 \\
\hline & A & $\mathrm{O}$ & 0.000 & 0.014 & 0.000 & 0.000 & 0.000 \\
\hline & B & $\mathrm{O}$ & 0.768 & 0.514 & 0.656 & 0.532 & 0.431 \\
\hline & $\mathrm{C}$ & A & 0.232 & 0.471 & 0.328 & 0.468 & 0.569 \\
\hline & D & (A) & 0.000 & 0.000 & 0.016 & 0.000 & 0.000 \\
\hline \multirow[t]{4}{*}{$M d h^{*}$} & $(N)$ & & 72 & 33 & 32 & 32 & 35 \\
\hline & A & A & 0.007 & 0.515 & 0.281 & 0.859 & 0.386 \\
\hline & B & (O) & 0.993 & 0.485 & 0.719 & 0.141 & 0.557 \\
\hline & $\mathrm{C}$ & A & 0.000 & 0.000 & 0.000 & 0.000 & 0.057 \\
\hline \multirow[t]{4}{*}{$M e^{*}$} & $(N)$ & & 62 & 26 & 18 & 20 & 36 \\
\hline & A & $\mathrm{O}$ & 0.968 & 0.192 & 0.333 & 0.050 & 0.000 \\
\hline & B & A & 0.032 & 0.769 & 0.611 & 0.950 & 1.00 \\
\hline & C & (O) & 0.000 & 0.038 & 0.056 & 0.000 & 0.000 \\
\hline \multirow[t]{4}{*}{$M p i^{*}$} & $(N)$ & & 73 & 34 & 32 & 32 & 36 \\
\hline & A & $\mathrm{O}$ & 0.048 & 0.000 & 0.016 & 0.000 & 0.000 \\
\hline & B & A & 0.281 & 0.838 & 0.781 & 0.938 & 1.00 \\
\hline & C & $\mathrm{O}$ & 0.671 & 0.162 & 0.203 & 0.063 & 0.000 \\
\hline \multirow[t]{5}{*}{ Pgm* } & $(N)$ & & 75 & 34 & 32 & 29 & 36 \\
\hline & A & $\mathrm{O}$ & 0.640 & 0.368 & 0.172 & 0.000 & 0.167 \\
\hline & B & A & 0.313 & 0.632 & 0.828 & 0.983 & 0.833 \\
\hline & C & A & 0.047 & 0.000 & 0.000 & 0.000 & 0.000 \\
\hline & D & $\mathrm{O}$ & 0.000 & 0.000 & 0.000 & 0.017 & 0.000 \\
\hline
\end{tabular}

(C) The Genetical Society of Great Britain, Heredity, 82, 462-469. 
Table 1 Cont.

\begin{tabular}{lccccccc}
\hline & & \multicolumn{3}{c}{ Population } \\
\cline { 4 - 8 } Locus* & Allele & $\begin{array}{c}\text { Allele in } \\
\text { hybrid indext: }\end{array}$ & $\begin{array}{c}\text { Wistman's } \\
\text { Wood }\end{array}$ & $\begin{array}{c}\text { Lydford } \\
\text { Gorge }\end{array}$ & Braunton & $\begin{array}{c}\text { Northum- } \\
\text { berland }\end{array}$ \\
\hline$P p^{*}$ & $(N)$ & & 68 & 33 & 32 & 27 & 35 \\
& $\mathrm{~A}$ & $\mathrm{O}$ & 0.978 & 0.712 & 0.531 & 0.796 & 0.271 \\
& $\mathrm{~B}$ & $\mathrm{~A}$ & 0.022 & 0.258 & 0.438 & 0.148 & 0.600 \\
& $\mathrm{C}$ & $\mathrm{A}$ & 0.000 & 0.030 & 0.031 & 0.056 & 0.129 \\
& $(N)$ & & 75 & 35 & 32 & 32 & 36 \\
& $\mathrm{~A}$ & - & 0.000 & 0.000 & 0.016 & 0.000 & 0.000 \\
& $\mathrm{~B}$ & - & 1.00 & 1.00 & 0.984 & 1.00 & 1.00 \\
\hline
\end{tabular}

*Used in hybrid index.

$\dagger$, occidentalis; A, asellus.

$\$$ Alleles whose subspecific designation is within parentheses are poorly differentiated and were assigned to the more appropriate taxon.

Alleles present only in intermediate populations were assigned to either asellus or occidentalis.

(London: one; Northumberland: one). However, some significant values of $R$ are negative, unexpected under deterministic gene flow, suggesting that genetic drift resulting from patchy population structure caused most of the sporadically significant disequilibria, rather than gene flow across a strongly selected hybrid zone.

\section{Inter-relationships between populations}

Values of Nei's unbiased genetic identity and distance both highlighted the distinction between the Wistman's Wood occidentalis populations and asellus, the Wistman's sample having a mean identity of 0.509 when compared with asellus. Mean identity between Wistman's and intermediate populations was 0.777 , identity between the two asellus populations being 0.955 . Values of genetic distance ranged from 0.700 (Wistman's Wood vs. Northumberland) to 0.042 (Lydford Gorge vs. London). The neighbour-joining phenogram of genetic identity, after correction for negative branch lengths, is shown in Fig. 2. The phenogram clusters the London and Northumberland populations (both asellus), and places the Wistman's occidentalis population at the other end of the network, with the hybrid populations (Lydford Gorge and Braunton) falling between the two extremes.

\section{Discussion}

The principal aim of the present study was to discover whether patterns of morphological differentiation within Oniscus asellus were supported by genetic data, and to investigate whether morphologically intermediate populations resulted from hybridization.

Bilton (1994) interpreted populations of intermediate morphology as arising through hybridization between

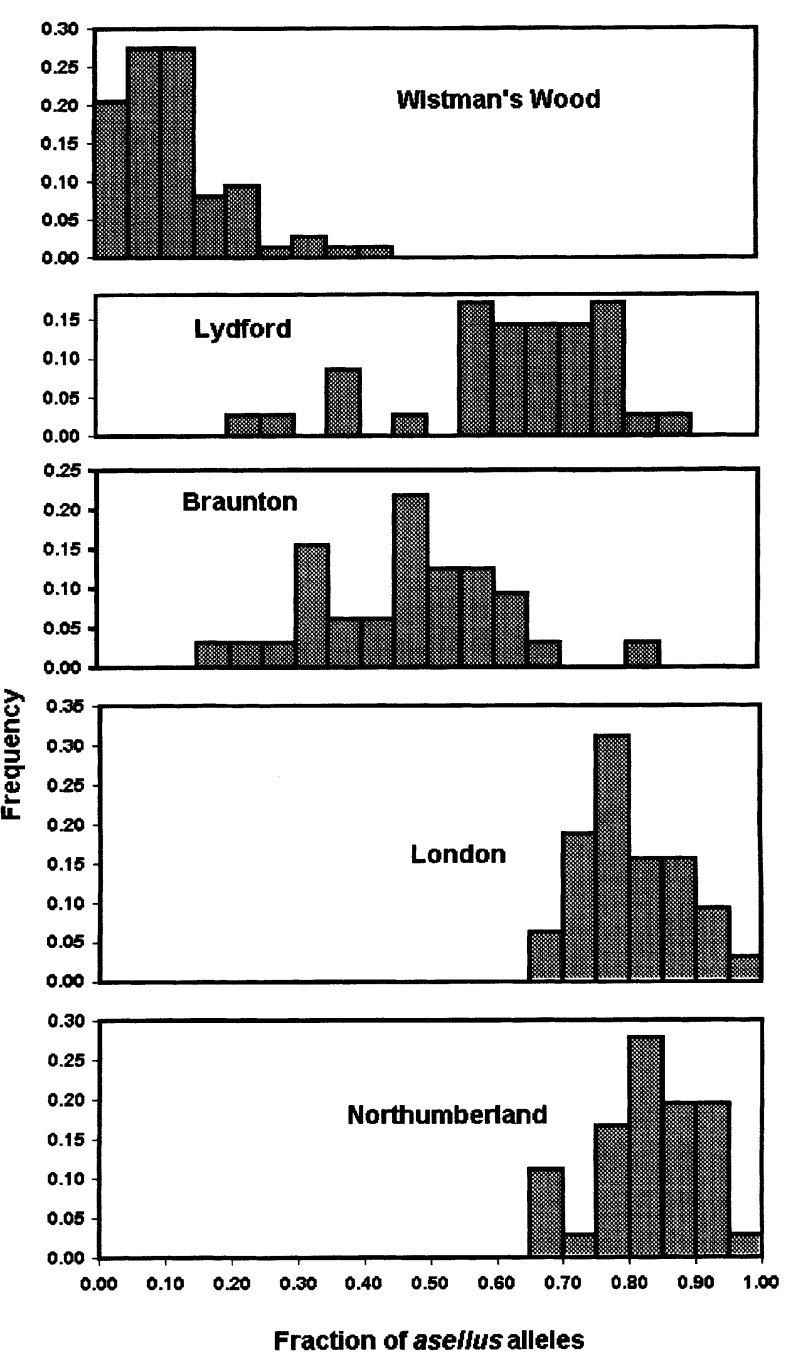

Fig. 1 Frequency distribution of asellus alleles at semidiagnostic loci for individuals in the five populations of Oniscus asellus $s$. lat. investigated.

(c) The Genetical Society of Great Britain, Heredity, 82, 462-469. 
Table 2 Measures of genetic variability within each population of Oniscus asellus s. lat.

\begin{tabular}{lccc}
\hline & $\begin{array}{c}\text { Loci } \\
\text { Pean no. } \\
\text { alleles/locus }\end{array}$ & $\begin{array}{c}\text { Mean } \\
\text { polymorphic* } \\
(\%)\end{array}$ & $\begin{array}{c}\text { heterozygosity/ } \\
\text { locus } \dagger\end{array}$ \\
\hline $\begin{array}{c}\text { Wistman's } \\
\quad \text { Wood }\end{array}$ & $2.15(0.15)$ & $53.9 / 76.9$ & $0.190(0.052)$ \\
$\begin{array}{c}\text { Lydford } \\
\quad \text { Gorge }\end{array}$ & $2.23(0.17)$ & $84.6 / 92.3$ & $0.349(0.046)$ \\
$\begin{array}{l}\text { Braunton } \\
\text { London }\end{array}$ & $2.46(0.14)$ & $92.3 / 100$ & $0.348(0.045)$ \\
$\begin{array}{c}\text { Northum- } \\
\text { berland }\end{array}$ & $1.00(0.16)$ & $53.9 / 84.6$ & $0.150(0.042)$ \\
\hline
\end{tabular}

Standard errors are given in parentheses.

$* 95 / 99 \%$ levels, respectively.

$\dagger$ Unbiased expected estimate (assumes Hardy-Weinberg equilibrium).

asellus and occidentalis subspecies. The genetic data presented here support this conclusion. Ten of the 13 loci scored have alternate alleles at high frequency in occidentalis and asellus populations, although none of these is entirely diagnostic. Allele frequency data (Table 1) confirm that the Braunton and Lydford populations contain the most even mixture of semidiagnostic alleles; this is also clearly displayed in the hybrid index scores (Fig. 1). Braunton and Lydford have the highest levels of genetic variability, reflecting probable mutual introgression of asellus and occidentalis genotypes.

Values of Nei's genetic distance between occidentalis and asellus populations (0.65-0.70) fall well above those expected of conspecific taxa, which are typically less than 0.15 (Avise \& Selander, 1972; Selander \& Johnson, 1973; Ayala et al., 1974; Emelianov et al., 1995). Although this strongly suggests that the taxa have had a long period of somewhat independent evolution affecting the majority of genetic loci, interpreting them as separate species would require a purely distancebased concept. Under the more traditional Biological Species Concept (Mayr, 1963), these taxa are clearly members of a single interbreeding community where they come in contact, and they would be classed as conspecific. There is also no evidence that the taxa form separate species under the genotypic cluster definition (Mallet, 1995); species defined via genotypic clusters should retain their integrity, and intermediates remain in a minority compared to parental forms in zones of overlap. This is not the case with Oniscus asellus, where intermediates are frequent in mixed populations in nature. Indeed pure occidentalis populations are rare, and in spite of the great genetic distance between asellus and occidentalis, the two forms are best considered as subspecies.

Over a wide area of southern England and western France intermediate Oniscus populations dominate most seminatural habitats. Rather than hybridization occurring in a narrow tension zone, the interaction

Table 3 Heterozygote deficit ( $\left.F_{\mathrm{IS}}\right)$ values by locus, and average gametic phase disequilibrium $(R)$ between lumped alleles in each population of Oniscus asellus s. lat.

\begin{tabular}{|c|c|c|c|c|c|c|}
\hline \multirow[b]{2}{*}{ Locus } & \multirow[b]{2}{*}{ Number of alleles } & \multicolumn{5}{|c|}{$F_{\text {IS }}$} \\
\hline & & Wistman's Wood & Lydford Gorge & Braunton & London & Northumberland \\
\hline$A c p$ & 3 & -0.009 & -0.015 & -0.057 & - & -0.029 \\
\hline Eno & 2 & $0.313^{* *}$ & $0.578^{* *}$ & 0.269 & -0.032 & - \\
\hline Got-1 & 3 & 0.134 & 0.011 & 0.331 & $0.526^{* *}$ & $1.000 * * *$ \\
\hline Got-2 & 2 & $0.402 * *$ & 0.111 & -0.026 & -0.670 & - \\
\hline Gpi & 2 & -0.340 & -0.039 & -0.039 & 0.049 & - \\
\hline Lgg-1 & 4 & 0.212 & 0.252 & -0.101 & -0.025 & 0.080 \\
\hline Lgg-2 & 4 & 0.186 & 0.332 & 0.187 & 0.158 & 0.264 \\
\hline$M d h$ & 3 & -0.007 & 0.272 & $0.536 * *$ & $0.612^{* *}$ & $0.203^{*}$ \\
\hline$M e$ & 3 & $1.000 * * *$ & $1.000 * * *$ & $1.000 * * *$ & $1.000 * * *$ & - \\
\hline$M p i$ & 3 & $0.444 * * *$ & $0.675^{* * *}$ & $0.372 *$ & 0.670 & - \\
\hline Pgm & 4 & $0.265^{* * *}$ & $0.684 * * *$ & $0.431 *$ & -0.018 & $0.800 * * *$ \\
\hline$P p$ & 3 & -0.023 & 0.146 & $0.524 * *$ & -0.195 & 0.013 \\
\hline \multirow[t]{4}{*}{$S d h$} & 2 & - & - & -0.016 & - & - \\
\hline & Mean $F_{\text {IS }}$ & 0.215 & 0.341 & 0.260 & 0.180 & 0.333 \\
\hline & Mean $R$ & 0.02 & 0.08 & 0.04 & -0.03 & 0.01 \\
\hline & $(\mathrm{SE}, n=45)$ & $(0.02)$ & $(0.03)$ & $(0.03)$ & $(0.02)$ & $(0.01)$ \\
\hline
\end{tabular}

$* P<0.05, * * P<0.01,{ }^{* * *} P<0.001$.

(c) The Genetical Society of Great Britain, Heredity, 82, 462-469. 
Table 4 Linkage disequilibria for populations of Oniscus asellus s. lat.

\begin{tabular}{|c|c|c|c|c|c|c|c|c|c|}
\hline & Got-1 & Got-2 & Lgg-1 & $L g g-2$ & $M d h$ & $M e$ & $M p i$ & Pgm & $P p$ \\
\hline Got-1 & & 00000 & 00000 & 00000 & 00000 & $00+\infty$ & ooo+o & 00000 & 00000 \\
\hline Lgg-1 & & & & 00000 & 00000 & 00000 & 00000 & ০+০০০ & 00000 \\
\hline$L g g-2$ & & & & & 00000 & o+o০০ & 00000 & 00000 & 00000 \\
\hline$M d h$ & & & & & & ০০-০০ & 00000 & 00000 & ০- - ০০ \\
\hline$M p i$ & & & & & & & & 00000 & 00000 \\
\hline Pgm & & & & & & & & & oooot \\
\hline
\end{tabular}

Significant positive $(+)$, negative $(-)$ and nonsignificant $\left(G_{1}<3.84\right.$, o) gametic correlations are shown between all pairs of loci. The string of five symbols represents results of tests at each site. Order of sites: Wistman's Wood, Lydford, Braunton, London, Northumberland.

\section{Wistman's Wood}

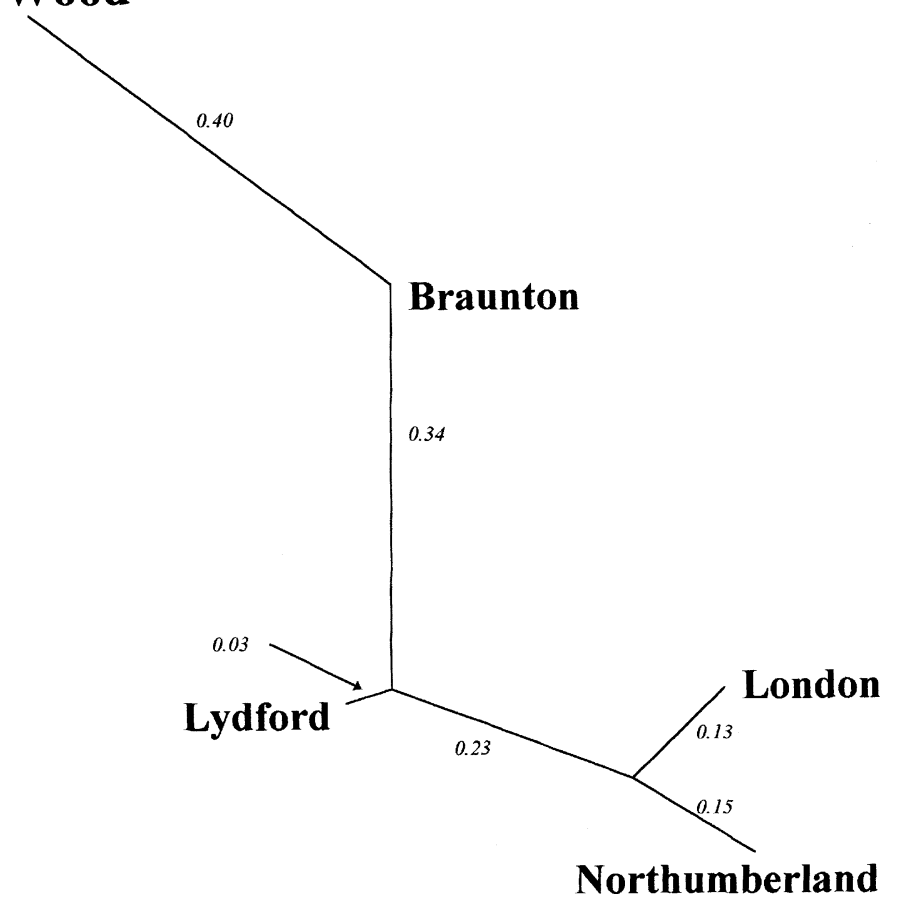

Fig. 2 Neighbour-joining phenogram (corrected for negative branch lengths) of Nei's unbiased genetic identity between the five populations of Oniscus asellus $s$. lat. sampled in the current study. Values in italics represent branch lengths. between the two asellus subspecies appears to be most analogous to that seen in a number of plant taxa (see Arnold, 1997) where hybridization results in a mosaic of populations of parents and hybrids, the exact location of which may be mediated by stochastic population dynamics and habitat. Stochastic colonization of habitat patches by woodlice appears to result in sporadic significant heterozygote deficits and linkage disequilibria locally. The lack of significant positive disequilibria between most pairs of loci suggests that gene flow is weak compared with the width of the hybrid belts (Barton \& Gale, 1993). Further genetic investigations of Oniscus populations along local transects would now be useful to test the ideas generated in this study.

\section{Acknowledgements}

We are grateful to Peter King for technical assistance, and to funding from the Weldon Foundation for the consumables.

\section{References}

ARNOLD, M. L. 1997. Natural Hybridization and Evolution. Oxford University Press, Oxford.

(c) The Genetical Society of Great Britain, Heredity, 82, 462-469. 
AVISE, J. C. AND SELANDER, R. K. 1972. Evolutionary genetics of cave-dwelling fishes of the genus Astyanax. Evolution, 26, $1-19$.

AYALA, F. J., TRACEY, M. L., HEDGECOCK, D. AND RICHMOND, R. 1974. Genetic differentiation during the speciation process in Drosophila. Evolution, 28, 576-592.

BARTON, N. H. AND GALE, K. S. 1993. Genetic analysis of hybrid zones. In: Harrison, R. G. (ed.) Hybrid Zones and the Evolutionary Process, pp. 13-45. Oxford University Press, New York.

BILTON, D. T. 1994. Intraspecific variation in the terrestrial isopod Oniscus asellus Linnaeus, 1758 (Crustacea: Isopoda: Oniscidea). Zool. J. Linn. Soc., 110, 325-354.

BILton, D. T. 1997. The Oniscus asellus complex (Crustacea: Isopoda: Oniscidea) in the Iberian Peninsula with the description of a new species. Rev. Suisse Zool., 104, 217-227.

EASTEAL, S. AND BOUSSY, I. A. 1987. A sensitive and efficient isoenzyme technique for small arthropods and other invertebrates. Bull. Ent. Res., 77, 407-415.

EMELIANOV, I., MALLET, J. AND BALTENSWEILER, W. 1995. Genetic differentiation in the larch budmoth Zeiraphera diniana (Lepidoptera: Tortricidae): polymorphism, host races or sibling species? Heredity, 75, 416-424.

FELSENSTEIN, J. 1993. PHYLIP (Phylogenetic inference package), version 3.5c. Department of Genetics, University of Washington, Seattle.

HEDRICK, P. W. 1987. Gametic disequilibrium measures: proceed with caution. Genetics, 117, 331-341.

HILL, W. G. 1974. Estimation of linkage disequilibrium in random mating populations. Heredity, 33, 229-239.
LEWONTIN, R. C. 1988. On measures of gametic disequilibrium. Genetics, 120, 849-852.

MALlET, J. 1995. A species definition for the Modern Synthesis. Trends Ecol. Evol., 10, 294-299.

MAYr, E. 1963. Animal Species and Evolution. Belknap Press of Harvard University Press, Cambridge, MA.

NEI, M. 1972. Genetic distance between populations. Am. Nat., 106, 283-292.

NEI, M. 1986. Molecular Evolutionary Genetics. Columbia University Press, New York.

RICHARDSON, B. J., BAVERSTOCK, P. R. AND ADAMS, M. 1986. Allozyme Electrophoresis. Academic Press, Canberra.

SELANDER, R. K. AND JOHNSON, W. E. 1973. Genetic variation among vertebrate species. Ann. Rev. Ecol. Syst., 4, 75-91.

SWOFFORD, D. L. AND SELANDER, R. B. 1989. BIOSYS-1. A computer program for the analysis of allelic variation in population genetics and biochemical systematics. Release 1.7. University of Illinois, Urbana, IL.

SWOFFORD, D. L., OLSEN, G. J., WADDELL, P. J. AND HILLIS, D. M. 1997. Phylogenetic Inference. In: Hillis, D. M., Moritz, C. and Mable, B. K. (eds) Molecular Systematics, 2nd edn, pp. 407-514. Sinauer Associates, Sunderland, MA.

WEIR, B. S. 1990. Genetic Data Analysis. Sinauer Associates, Sunderland, MA.

WRIGHT, S. 1965. The interpretation of population structure by F-statistics with special regard to systems of mating. Evolution, 19, 395-420.

WRIGHT, s. 1978. Evolution and the Genetics of Populations, vol. 4, Variability Within and Among Natural Populations. University of Chicago Press, Chicago. 